\title{
Mesorhizobium metallidurans sp. nov., a metal- resistant symbiont of Anthyllis vulneraria growing on metallicolous soil in Languedoc, France
}

Correspondence Jean-Claude Cleyet-Marel cleyet@supagro.inra.fr

\author{
Céline Vidal, ${ }^{1}$ Clémence Chantreuil, ${ }^{2}$ Odile Berge, ${ }^{3}$ Lucette Mauré, ${ }^{1}$ \\ José Escarré, ${ }^{4}$ Gilles Béna, ${ }^{2}$ Brigitte Brunel ${ }^{5}$ \\ and Jean-Claude Cleyet-Marel ${ }^{1}$
}

\begin{abstract}
${ }^{1}$ INRA, USC1242, Laboratoire des Symbioses Tropicales et Méditerranéennes, Campus International de Baillarguet TA A-82/J, F-34398, Montpellier Cedex 5, France

${ }^{2}$ IRD, UMR 113, Laboratoire des Symbioses Tropicales et Méditerranéennes, F-34398 Montpellier, France

${ }^{3}$ CNRS, UMR 6191, Laboratoire d'Ecologie Microbienne de la Rhizosphère et des Environnements Extrêmes, F-13108 Saint-Paul lez Durance, France

${ }^{4}$ CNRS, UMR 5175, Centre d'Ecologie Fonctionnelle et Evolutive, 1919 Route de Mende, F-34293 Montpellier, France

${ }^{5}$ Montpellier SupAgro, UMR 113, Laboratoire des Symbioses Tropicales et Méditerranéennes, F-34398 Montpellier, France
\end{abstract}

In the Languedoc region of the south of France, the zincmining area at Saint Laurent le Minier had been exploited for 120 years, and closed in 1991. One of the few plant species growing on the heavy metal-enriched spoil heaps of the area (5-15\% Zn) is Anthyllis vulneraria, a plant associated with a nitrogen-fixing Rhizobium. Together, they are an interesting tool for post-mining restoration (Frérot et al., 2006). Indeed, plants of the family Leguminosae are of general environmental interest; bacteria, in association with legumes, can reduce atmospheric dinitrogen to organic nitrogen and thus

The GenBank/EMBL/DDBJ accession numbers for the sequences determined in this study are AM930381-AM930393.

A table showing GenBank accession numbers for individual sequences is available with the online version of this paper. can greatly increase plant growth and stimulate soil fertility. The bacteria that form nitrogen-fixing nodules on leguminous plants belong to both the Alphaproteobacteria and Betaproteobacteria. Some of these species belong to the genus Mesorhizobium, which was first described by Jarvis et al. (1997). At the time of writing, this genus comprises 12 recognized species, namely Mesorhizobium loti (Jarvis et al., 1982), M. huakuii (Chen et al., 1991), M. ciceri (Nour et al., 1994), M. mediterraneum (Nour et al., 1995), M. tianshanense (Chen et al., 1995), M. plurifarium (de Lajudie et al., 1998), M. amorphae (Wang et al., 1999), M. chacoense (Velazquez et al., 2001), M. septentrionale (Gao et al., 2004), M. temperatum (Gao et al., 2004), M. thiogangeticum (Ghosh \& Roy, 2006) and M. albiziae (Wang et al., 2007). 
The presence of nodules on A. vulneraria root systems was first observed from plants excavated directly from the mine site of Saint Laurent le Minier. Bacterial isolates nodulating this plant species were subsequently obtained from soil samples by trapping with $A$. vulneraria. Seeds of $A$. vulneraria used for both trapping and nodulation investigation were collected in bulk from the same site of Saint Laurent le Minier. Thirty-one rhizobia were isolated from nodules harvested from 30 plants. Nodules were surfacesterilized with $300 \mu \mathrm{H} \mathrm{H}_{2} \mathrm{O}_{2}$ (70\%) for $2 \mathrm{~min}$, rinsed with distilled water (five times) and crushed in $50 \mu \mathrm{l}$ sterile distilled water. The suspension was streaked on yeast extract mannitol (YEM) medium (Vincent, 1970). Colonies appeared after $2-3$ weeks incubation at $28{ }^{\circ} \mathrm{C}$ under aerobic conditions and were checked for purity by repeated streaking on YEM agar. All strains were kept in $20 \%$ glycerol $(\mathrm{v} / \mathrm{v})$ at $-80{ }^{\circ} \mathrm{C}$.

The nodulating ability of the 31 mesorhizobial isolates was verified. Seeds were scarified and surface-sterilized with sulfuric acid for $2 \mathrm{~min}$ and then rinsed with distilled water (five times). Seeds were incubated to allow germination in sterile Petri dishes with $1 \%$ water agar for $48 \mathrm{~h}$ at $4{ }^{\circ} \mathrm{C}$ and then for $48 \mathrm{~h}$ at $28{ }^{\circ} \mathrm{C}$. Plants were transferred to tubes containing clay granules as rooting substrate (Damolin) and $40 \mathrm{ml}$ mineral nutritive solution lacking nitrogen (Bertrand et al., 2000). Each tube was inoculated with one rhizobial suspension from an early-stationary-phase culture. Ten replicates were prepared for each treatment. After 7 weeks, plants were harvested and analysed for nodule occurrence. Observations confirmed that all bacterial isolates had the ability to nodulate the original host plant, A. vulneraria.

In order to assess the taxonomic position of the 31 rhizobia, a phylogenetic analysis was performed. The nearly full-length 16S rRNA genes (1399 bp) were amplified and their sequences were determined from the PCR products by using universal primers (Normand et al., 1992). The genus Mesorhizobium contains several species that share high 16S rRNA gene sequence similarity (Gao et al., 2004; Kwon et al., 2005). Therefore, data from additional gene sequences are usually needed for species delineation within this genus. Phylogenies of the $r e c A$ gene (encoding part of the DNA recombination and repair system) and atpD gene (encoding the $\beta$ chain of ATP synthase) in rhizobial taxa (Gaunt et al., 2001; Vinuesa et al., 2005; Weir et al., 2004) have been shown to be congruent with those of the $16 \mathrm{~S}$ rRNA gene, with well-supported clades grouping Mesorhizobium species with high levels of bootstrap support (Gaunt et al., 2001). The two housekeeping genes recA and atpD were amplified by using published primers (Gaunt et al., 2001) and resulted in two DNA fragments of 469 and $433 \mathrm{bp}$, respectively. Sequences obtained were compared with sequences retrieved from GenBank by using the BLASTN program (Altschul et al., 1990). Multiple nucleotide sequence alignments were generated by using CLUSTAL_X version 1.83 (Thompson et al., 1997) and were optimized manually by using GeneDoc 2.6.002 (Nicholas \& Nicholas, 1997). Phylogenetic trees were inferred with the neighbour-joining (Saitou \& Nei, 1987) and maximumlikelihood (Yang, 1997) methods by using PAUP version $4.0 \mathrm{~b} 10$ (Swofford, 1998). For recA and atpD gene sequence analyses, we estimated the best likelihood model for each dataset by using MODELTEST (Posada \& Crandall, 1998), and we consequently applied a GTR + G model (general timereversible with rates across sites assumed to follow a continuous gamma distribution). Trees were obtained by using a heuristic search implemented in PAUP. Bootstrap analysis was based on 1000 resamplings to validate the reliability of the branching pattern of the tree. All trees were visualized by using TreeView version 1.6.6 (Page, 1996). Trees were rooted by using the type strain of Bradyrhizobium japonicum as an outgroup. The neighbourjoining and maximum-likelihood methods produced similar results for the 16S rRNA gene sequence analyses (data not shown).

The 16S rRNA gene sequences of the 31 new isolates analysed showed $100 \%$ similarity. Fig. 1 shows the neighbour-joining phylogenetic tree based on full-length $16 \mathrm{~S}$ rRNA gene sequences. The closest relative to the novel strains was the type strain of $M$. tianshanense $(99.7 \%$ similarity), and in the neighbour-joining tree these clustered together with $>90 \%$ bootstrap support.

These phylogenetic relationships among the new isolates and other Mesorhizobium species were confirmed by recA

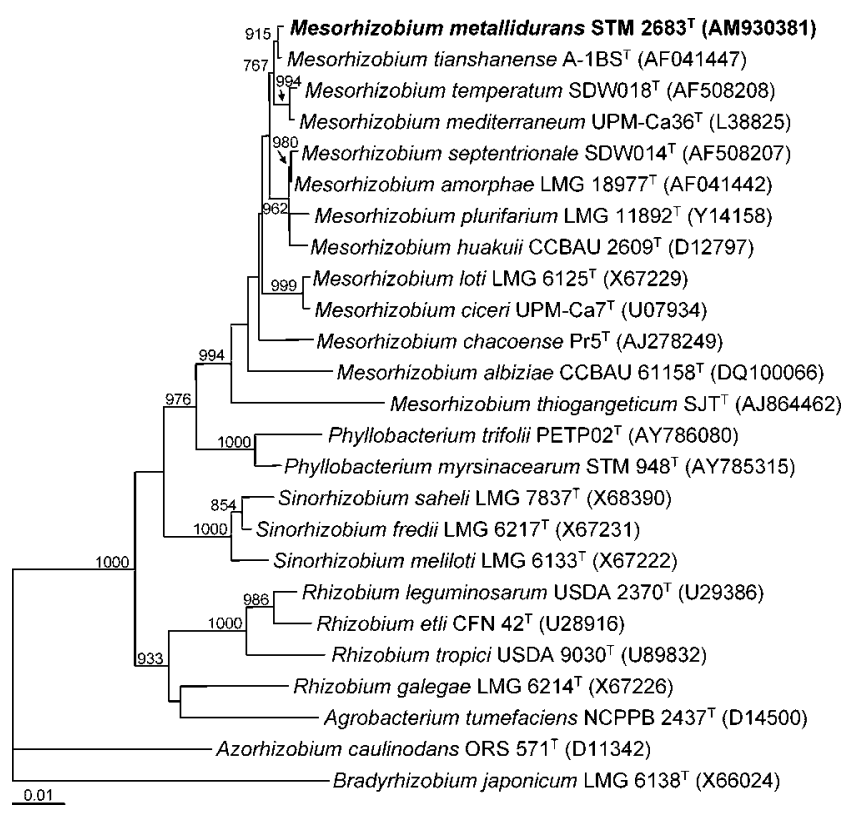

Fig. 1. Neighbour-joining phylogenetic tree based on 16S rRNA gene sequences, showing the relationships between strain STM $2683^{\top}$ and the type strains of reference species. The analysis was based on $1399 \mathrm{nt}$. GenBank accession numbers are given in parentheses, and the significance of each branch is indicated by a bootstrap value (when $\geqslant 700$ ) calculated for 1000 subsets at major branch points. Bar, 1 substitution per $100 \mathrm{nt}$. 
and atpD gene sequence analyses (Fig. 2). The 31 rhizobia isolated from $A$. vulneraria clustered together and diverged from M. tianshanense ORS $2640^{\mathrm{T}}$ and M. mediterraneum ORS $2739^{\mathrm{T}}$ as sister clades. Compared with the $16 \mathrm{~S}$ rRNA gene sequences of the novel strains, which were identical, the recA and atpD gene sequences displayed some variability (95.9-99.8 and $96.5-99.7 \%$ similarity, respectively), and their analyses allowed the distinction of six closely related clusters among the 31 strains (Fig. 2). GenBank accession numbers for individual sequences are given in Supplementary Table S1 (available in IJSEM Online).

DNA-DNA hybridization was carried out with a fluorometric method by using photobiotin-labelled DNA probes (Ezaki et al., 1989), following the recommendations of
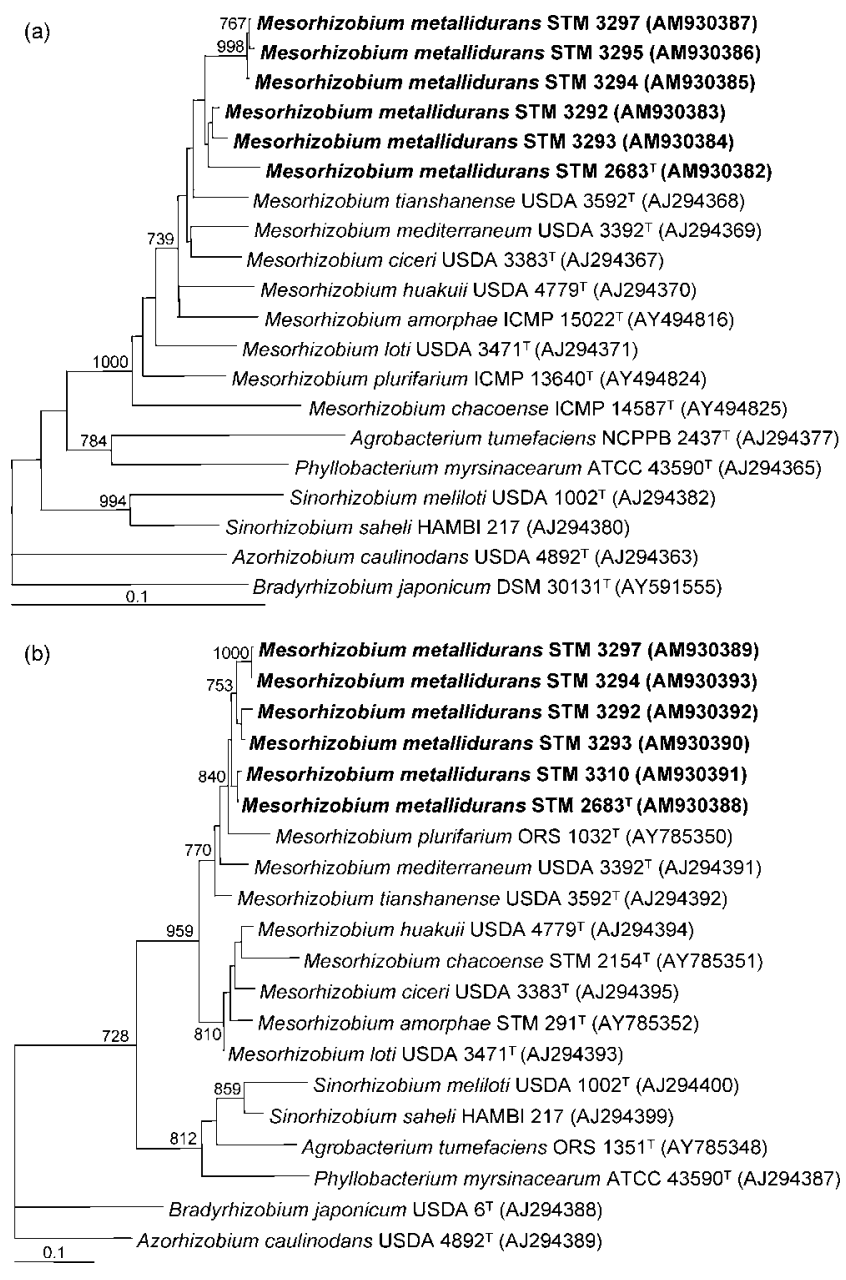

Fig. 2. Phylogenetic trees constructed by using (a) $\operatorname{rec} A$ and (b) atp $D$ gene sequences. The analyses were based on 469 and $433 \mathrm{nt}$, respectively. Maximum-likelihood trees were constructed by using a GTR + G model via the program PAUP. GenBank accession numbers are given in parentheses, and the significance of each branch is indicated by a bootstrap value (when $\geqslant 700$ ) calculated for 1000 subsets at major branch points. Bars, 10 substitutions per 100 nt.
Willems et al. (2001). The five strains showing highest recA and atpD gene sequence dissimilarity were analysed. The hybridization temperature was $42{ }^{\circ} \mathrm{C}$. At least four repetitions were performed, and self-hybridization of the probe with homologous target DNA was set at $100 \%$. The novel mesorhizobial strains isolated from $A$. vulneraria showed $>73 \%$ DNA-DNA relatedness, compared with 19-33\% DNA-DNA relatedness between these strains and M. tianshanense ORS $2640^{\mathrm{T}}$ and M. mediterraneum ORS $2739^{\mathrm{T}}$ (Table 1). Given the recommended threshold value of $70 \%$ DNA-DNA relatedness for the definition of a species (Wayne et al., 1987), these results indicate that the strains isolated from A. vulneraria should be considered as representing a novel species.

Among the 31 isolates from A. vulneraria, five strains (STM $2683^{\mathrm{T}}$, STM 3291, STM 3292, STM 3293 and STM 3294), chosen as described above, and reference strains of Mesorhizobium were characterized phenotypically. Classical phenotypic features and the ability to tolerate zinc and cadmium were examined. In total, 138 phenotypic characteristics were analysed. Assimilation of substrates was determined by using the API 100 , API $50 \mathrm{CH}$ and API 20NE systems (bioMérieux). Tests for antibiotic resistance, tolerance to different concentrations of $\mathrm{NaCl}$, and temperature and $\mathrm{pH}$ ranges for growth were performed in YEM. The optimal growth temperature was $28^{\circ} \mathrm{C}$. None of the strains was able to grow at 4 or $41{ }^{\circ} \mathrm{C}$. Table 2 shows the key phenotypic characteristics that can be used to distinguish the rhizobial strains isolated from metallicolous A. vulneraria from the other Mesorhizobium species and Rhizobium galegae. As shown in Table 2, the novel strains differed from recognized Mesorhizobium species in the assimilation of 21 carbon sources. No difference in antibiotic resistance was found.

To test for metal resistance, the strains were grown on YEM liquid medium with increasing concentrations of zinc (in the form of $\mathrm{ZnSO}_{4}$ ) of $0.02,0.05,0.1,0.3,0.5,1,2,4,6,8$, $10,12,16$ and $32 \mathrm{mM}$, and cadmium (in the form of $\mathrm{CdCl}_{2}$ ) of $0.02,0.05,0.1,0.3,0.5,0.8$ and $1 \mathrm{mM}$. Each metal concentration was tested in triplicate and each bacterial culture was incubated at $28{ }^{\circ} \mathrm{C} . \mathrm{OD}_{620}$ was measured after 2 weeks growth. The lowest concentration that prevented growth was considered the minimum inhibitory concentration (Andrews, 2001). The strains isolated from A. vulneraria tolerated high concentrations of heavy metals, $16-32 \mathrm{mM} \mathrm{Zn}$ and $0.3-0.5 \mathrm{mM} \mathrm{Cd}$, whereas M. tianshanense ORS $2640^{\mathrm{T}}$ and M. mediterraneum ORS $2739^{\mathrm{T}}$ were able to tolerate only low concentrations, $0.05-0.5 \mathrm{mM} \mathrm{Zn}$ and $0.05 \mathrm{mM} \mathrm{Cd}$.

Microbes apply various types of resistance mechanisms in response to heavy metals (Nies, 2003). These mechanisms, often based on efflux systems, may be encoded by chromosomal genes, but loci conferring resistance are more usually located on plasmids (Cervantes \& GutierrezCorona, 1994; Wuertz \& Mergeay, 1997). The resistance systems of the strains isolated from A. vulneraria, which 
Table 1. Levels of DNA-DNA relatedness among five Mesorhizobium strains isolated from Anthyllis vulneraria and the type strains of $M$. tianshanense and $M$. mediterraneum

ND, Not determined.

\begin{tabular}{|c|c|c|c|c|c|}
\hline \multicolumn{2}{|c|}{ Strain } & \multicolumn{4}{|c|}{$\begin{array}{l}\text { DNA-DNA relatedness } \\
\text { (\%) with DNA of strain: }\end{array}$} \\
\hline & & 1 & 2 & 3 & 4 \\
\hline 1 & $\begin{array}{l}\text { M. tianshanense } \\
\text { ORS } 2640^{\mathrm{T}}\end{array}$ & 100 & & & \\
\hline 2 & STM $2683^{\mathrm{T}}$ & 29 & 100 & & \\
\hline 3 & STM 3293 & 28 & 82 & 100 & \\
\hline 4 & STM 3297 & ND & 78 & 88 & 100 \\
\hline 5 & STM 3294 & 33 & 77 & 77 & 89 \\
\hline 6 & STM 3292 & 18 & 73 & 91 & $\mathrm{ND}$ \\
\hline 7 & $\begin{array}{l}\text { M. mediterraneum } \\
\text { ORS } 2739^{\mathrm{T}}\end{array}$ & 19 & 27 & 24 & ND \\
\hline
\end{tabular}

tolerated high concentrations of $\mathrm{Zn}$ and $\mathrm{Cd}$, remain unknown.

From the above data, the 31 heavy metal-tolerating isolates from root nodules of $A$. vulneraria are considered to represent a single, novel species of the genus Mesorhizobium, for which the name Mesorhizobium metallidurans sp. nov. is proposed.

\section{Description of Mesorhizobium metallidurans sp. nov.}

Mesorhizobium metallidurans (me.tal.li.du'rans. L. n. metallum metal; L. pres. part. durans enduring; N.L. part. adj. metallidurans enduring metal, referring to the metal resistance of strains of the species).

Gram-negative, aerobic, non-spore-forming rods. Colonies appearing on YEM agar within 3-5 days incubation at $28{ }^{\circ} \mathrm{C}$ are circular, opaque, convex and cream-coloured. The maximum temperature for aerobic growth is $37{ }^{\circ} \mathrm{C}$; some strains can tolerate $1 \% \mathrm{NaCl}$ and grow over a $\mathrm{pH}$ range of $5-11$. Nodulates the legume Anthyllis vulneraria. Tolerates high concentrations of heavy metals: $16-32 \mathrm{mM}$ zinc and $0.3-0.5 \mathrm{mM}$ cadmium. Resistant to penicillin $\mathrm{G}$ $\left(10 \mu \mathrm{g} \mathrm{ml}^{-1}\right)$, erythromycin $\left(15 \mu \mathrm{g} \mathrm{ml}^{-1}\right)$ and cefuroxime $\left(30 \mu \mathrm{g} \mathrm{ml}^{-1}\right)$; susceptible to ampicillin $\left(10 \mu \mathrm{g} \mathrm{ml}^{-1}\right)$, gentamicin $\left(10 \mu \mathrm{g} \mathrm{ml}^{-1}\right)$, polymyxin $\mathrm{B}\left(300 \mu \mathrm{g} \mathrm{ml}^{-1}\right)$ and tetracycline $\left(30 \mu \mathrm{g} \mathrm{ml}^{-1}\right)$. Assimilates lactulose, Ltryptophan, 4-aminobutyrate, proline, glycerol, arabinose,

Table 2. Differential phenotypic characteristics among five strains isolated from Anthyllis vulneraria, the type strains of recognized Mesorhizobium species and the type strain of Rhizobium galegae

Strains: 1, STM 2683 ${ }^{\mathrm{T}}$, STM 3291, STM 3292, STM 3293 and STM 3294; 2, M. tianshanense ORS 2640 ${ }^{\mathrm{T}}$; 3, M. mediterraneum ORS $2739^{\mathrm{T}}$; 4 , M. amorphae LMG $18977^{\mathrm{T}} ; 5$, M. huakuii CCBAU $2609^{\mathrm{T}} ; 6$, M. chacoense LMG $19008^{\mathrm{T}} ; 7$, M. temperatum SDW018 ${ }^{\mathrm{T}} ; 8$, M. plurifarium LMG $11892^{\mathrm{T}}$; 9 , M. septentrionale SDW014 ${ }^{\mathrm{T}}$; 10, M. albiziae CCBAU $61158^{\mathrm{T}}$ (data from Wang et al., 2007); 11, M. thiogangeticum SJT ${ }^{\mathrm{T}}$ (Ghosh \& Roy, 2006); 12, M. ciceri UPM-Ca7 ${ }^{\mathrm{T}}$; 13, M. loti NZP $2213^{\mathrm{T}}$; 14, R. galegae ATCC $43677^{\mathrm{T}}$ (Nour et al., 1994). +, Positive; - , negative; \pm , weakly positive; ND, not determined.

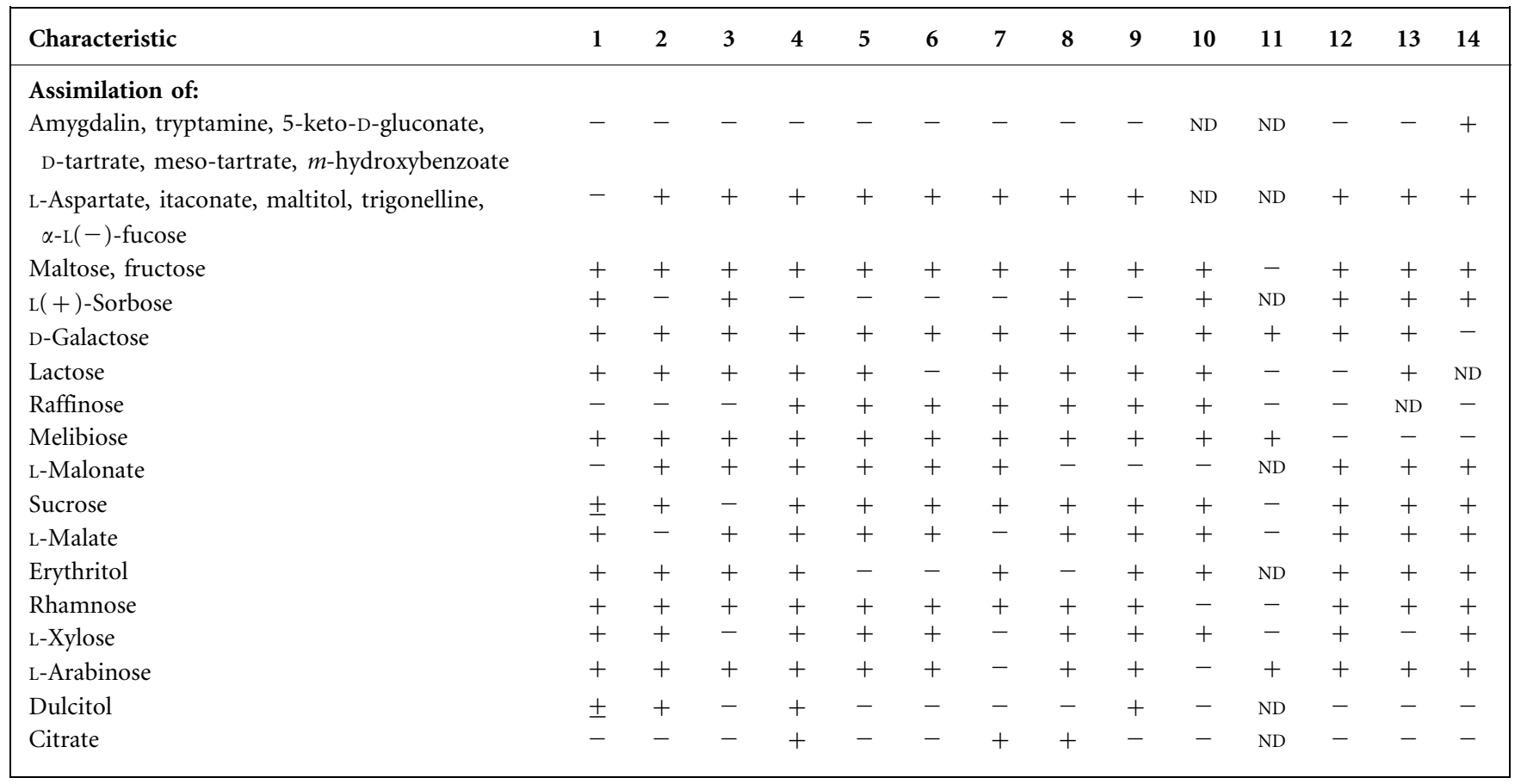


ribose, xylose, sorbose, adonitol, methyl $\beta$-D-xylopyranoside, glucose, aesculin, turanose and lyxose. Utilization of galactose, fructose, D-mannose, rhamnose, dulcitol, inositol, mannitol, sorbitol, cellobiose, maltose, lactose, sucrose, trehalose, xylitol, L-alanine, arabitol, methyl galactopyranoside, saccharate, cis-aconitate, citrate, glucuronate, galacturonate, quinate, histamine, caprylate, succinate, glutarate, glutamate, propionate and tyrosine as sole carbon source is strain-dependent. No growth is observed with fucose, maltotriose, palatinose, melezitose, maltitol, trigonelline, malonate, methyl D-glucopyranose, mucate, tartrate, L-aspartate, trans-aconitate, triscarballylate, protocatechuate, hydroxybenzoate, gentisate, benzoate, 3-phenylpropionate, coumarate, putrescine, lactate, caprate, 5aminovalerate, ethanolamine, tryptamine, itaconate, Dalanine, L-serine, $\alpha$-ketoglutarate, methyl $\alpha$-D-mannopyranoside, methyl $\alpha$-D-glucopyranoside, amygdalin, arbutin, salicin, inulin, melezitose, raffinose, starch, glycogen or potassium ketogluconate.

The type strain, STM $2683^{\mathrm{T}} \quad\left(=\mathrm{CFBP} \quad 7147^{\mathrm{T}}=\mathrm{LMG}\right.$ $\left.24485^{\mathrm{T}}\right)$, was isolated from root nodules of Anthyllis vulneraria found on heavy metal-enriched spoil heaps at the Saint Laurent le Minier mine (Languedoc, France).

\section{Acknowledgements}

This work was supported by an 'Agence De l'Environnement et de la Maîtrise de l'Energie' (ADEME) contract (04.72.C.0037). C. V. was supported by a PhD fellowship from ADEME and the Languedoc Roussillon region.

\section{References}

Altschul, S. F., Gish, W., Miller, W., Myers, E. W. \& Lipman, D. J. (1990). Basic local alignment search tool. J Mol Biol 215, 403-410.

Andrews, J. M. (2001). Determination of minimum inhibitory concentrations. J Antimicrob Chemother 48, 5-16.

Bertrand, H., Plassard, C., Pinochet, X., Touraine, B., Normand, P. \& Cleyet-Marel, J.-C. (2000). Stimulation of the ionic-transport system in Brassica napus by a plant growth-promoting rhizobacterium (Achromobacter sp.). Can J Microbiol 46, 229-236.

Cervantes, C. \& Gutierrez-Corona, F. (1994). Copper resistance mechanisms in bacteria and fungi. FEMS Microbiol Rev 14, 121-137.

Chen, W. X., Li, G. S., Qi, Y. L., Wang, E. T., Yuan, H. L. \& Li, J. L. (1991). Rhizobium huakuii sp. nov. isolated from the root nodules of Astragalus sinicus. Int J Syst Bacteriol 41, 275-280.

Chen, W., Wang, E., Wang, S., Li, Y. \& Chen, X. (1995). Characteristics of Rhizobium tianshanense sp. nov., a moderately and slowly growing root nodule bacterium isolated from an arid saline environment in Xinjiang, People's Republic of China. Int J Syst Bacteriol 45, 153-159.

de Lajudie, P., Willems, A., Nick, G., Moreira, F., Molouba, F., Hoste, B., Torck, U., Neyra, M., Collins, M. D. \& other authors (1998). Characterization of tropical tree rhizobia and description of Mesorhizobium plurifarium sp. nov. Int J Syst Bacteriol 48, 369-382.

Ezaki, T., Hashimoto, Y. \& Yabuuchi, E. (1989). Fluorometric deoxyribonucleic acid-deoxyribonucleic acid hybridization in microdilution wells as an alternative to membrane filter hybridization in which radioisotopes are used to determine genetic relatedness among bacterial strains. Int J Syst Bacteriol 39, 224-229.
Frérot, H., Lefèbvre, C., Gruber, W., Collin, C., Dos Santos, A. \& Escarré, J. (2006). Specific interactions between local metallicolous plants improve the phytostabilization of mine soils. Plant Soil 282, 53-65.

Gao, J.-L., Turner, S. L., Kan, F. L., Wang, E. T., Tan, Z. Y., Qiu, Y. H., Gu, J., Terefework, Z., Young, J. P. \& other authors (2004). Mesorhizobium septentrionale sp. nov. and Mesorhizobium temperatum sp. nov., isolated from Astragalus adsurgens growing in the northern regions of China. Int J Syst Evol Microbiol 54, 2003-2012.

Gaunt, M. W., Turner, S. L., Rigottier-Gois, L., Lloyd-Macgilp, S. A. \& Young, J. P. W. (2001). Phylogenies of atpD and recA support the small subunit rRNA-based classification of rhizobia. Int J Syst Evol Microbiol 51, 2037-2048.

Ghosh, W. \& Roy, P. (2006). Mesorhizobium thiogangeticum sp. nov., a novel sulfur-oxidizing chemolithoautotroph from rhizosphere soil of an Indian tropical leguminous plant. Int J Syst Evol Microbiol 56, 9197.

Jarvis, B. D. W., Pankhurst, C. E. \& Patel, J. J. (1982). Rhizobium loti, a new species of legume root nodule bacteria. Int J Syst Bacteriol 32, 378-380.

Jarvis, B. D. W., van Berkum, P., Chen, W. X., Nour, S. M., Fernandez, M. P., Cleyet-Marel, J. C. \& Gillis, M. (1997). Transfer of Rhizobium loti, Rhizobium huakuii, Rhizobium ciceri, Rhizobium mediterraneum, and Rhizobium tianshanense to Mesorhizobium gen. nov. Int J Syst Bacteriol 47, 895-898.

Kwon, S.-W., Park, J.-Y., Kim, J.-S., Kang, J.-W., Cho, Y.-H., Lim, C.-K., Parker, M. A. \& Lee, G.-B. (2005). Phylogenetic analysis of the genera Bradyrhizobium, Mesorhizobium, Rhizobium and Sinorhizobium on the basis of $16 \mathrm{~S}$ rRNA gene and internally transcribed spacer region sequences. Int J Syst Evol Microbiol 55, 263-270.

Nicholas, K. B. \& Nicholas, H. B. (1997). GeneDoc: a tool for editing and annotating multiple sequence alignments, v2.6.001. Distributed by the authors. http://www.nrbsc.org/gfx/genedoc/

Nies, D. H. (2003). Efflux-mediated heavy metal resistance in prokaryotes. FEMS Microbiol Rev 27, 313-339.

Normand, P., Cournoyer, B., Simonet, P. \& Nazaret, S. (1992). Analysis of a ribosomal RNA operon in the actinomycete Frankia. Gene 111, 119-124.

Nour, S. M., Fernandez, M. P., Normand, P. \& Cleyet-Marel, J. C. (1994). Rhizobium ciceri sp. nov., consisting of strains that nodulate chickpeas (Cicer arietinum L.). Int J Syst Bacteriol 44, 511-522.

Nour, S. M., Cleyet-Marel, J. C., Normand, P. \& Fernandez, M. P. (1995). Genomic heterogeneity of strains nodulating chickpeas (Cicer arietinum L.) and description of Rhizobium mediterraneum sp. nov. Int J Syst Bacteriol 45, 640-648.

Page, R. D. (1996). TreeView: an application to display phylogenetic trees on personal computers. Comput Appl Biosci 12, 357-358.

Posada, D. \& Crandall, K. (1998). MODELTEST: testing the model of DNA substitution. Bioinformatics 14, 817-818.

Saitou, N. \& Nei, M. (1987). The neighbor-joining method: a new method for reconstructing phylogenetic trees. Mol Biol Evol 4, 406425.

Swofford, D. L. (1998). PAUP: Phylogenetic analysis using parsimony (and other methods). Sunderland, MA: Sinauer Associates.

Thompson, J. D., Gibson, T. J., Plewniak, F., Jeanmougin, F. \& Higgins, D. G. (1997). The CLUSTAL_X windows interface: flexible strategies for multiple sequence alignment aided by quality analysis tools. Nucleic Acids Res 25, 4876-4882.

Velazquez, E., Igual, J., Willems, A., Fernández, M. P., Muñoz, E., Mateos, P. F., Abril, A., Toro, N., Normand, P. \& other authors (2001). Mesorhizobium chacoense sp. nov., a novel species that nodulates 
Prosopis alba in the Chaco Arido region (Argentina). Int J Syst Evol Microbiol 51, 1011-1021.

Vincent, J. M. (1970). The cultivation, isolation and maintenance of rhizobia. In A Manual for the Practical Study of the Root-Nodule Bacteria, pp. 1-13. Edited by J. M. Vincent. Oxford: Blackwell Scientific.

Vinuesa, P., Silva, C., Lorite, M. J., Izaguirre-Mayoral, M. L., Bedmar, E. J. \& Martinez-Romero, E. (2005). Molecular systematics of rhizobia based on maximum likelihood and Bayesian phylogenies inferred from $r r s$, atpD, recA and nifH sequences, and their use in the classification of Sesbania microsymbionts from Venezuelan wetlands. Syst Appl Microbiol 28, 702-716.

Wang, E. T., van Berkum, P., Sui, X. H., Beyene, D., Chen, W. X. \& Martinez-Romero, E. (1999). Diversity of rhizobia associated with Amorpha fruticosa isolated from Chinese soils and description of Mesorhizobium amorphae sp. nov. Int J Syst Bacteriol 49, 51-65.

Wang, F. Q., Wang, E. T., Liu, J., Chen, Q., Sui, X. H., Chen, W. F. \& Chen, W. X. (2007). Mesorhizobium albiziae sp. nov., a novel bacterium that nodulates Albizia kalkora in a subtropical region of China. Int J Syst Evol Microbiol 57, 1192-1199.
Wayne, L. G., Brenner, D. J., Colwell, R. R., Grimont, P. A. D., Kandler, O., Krichevsky, M. I., Moore, L. H., Moore, W. E. C., Murray, R. G. E. \& other authors (1987). International Committee on Systematic Bacteriology. Report of the ad hoc committee on reconciliation of approaches to bacterial systematics. Int J Syst Bacteriol 37, 463-464.

Weir, B. S., Turner, S. J., Silvester, W. B., Park, D.-C. \& Young, J. M. (2004). Unexpectedly diverse Mesorhizobium strains and Rhizobium leguminosarum nodulate native legume genera of New Zealand, while introduced legume weeds are nodulated by Bradyrhizobium species. Appl Environ Microbiol 70, 5980-5987.

Willems, A., Doignon-Bourcier, F., Goris, J., Coopman, R., de Lajudie, P., De Vos, P. \& Gillis, M. (2001). DNA-DNA hybridization study of Bradyrhizobium strains. Int J Syst Evol Microbiol 51, 13151322.

Wuertz, S. \& Mergeay, M. (1997). Impact of heavy metals on soil microbial communities and their activities. In Modern Soil Microbiology, pp. 607-642. Edited by J. D. Elsas, J. T. Trevors \& E. M. H. Wellington. New York: Marcel Dekker.

Yang, Z. (1997). PAML: a program package for phylogenetic analysis by maximum likelihood. Comput Appl Biosci 15, 555-556. 